Pulsed methylprednisolone for rheumatoid arthritis

Sir: A recently published letter in the Annals suggested that pulse methylprednisolone therapy led to the death of a 71 year old patient, and the authors stated that they 'would be extremely wary of allowing pulse therapy to become an outpatient procedure' This seems to be an overreaction to an unfortunate death in a patient, where there were several possible contributing factors (methylprednisolone pulse therapy, intravenous access, azathioprine treatment, admission to hospital, age).

We have previously reported one patient who developed an infection of his rheumatoid nodule with the same organism that colonised his intravenous cannula. ${ }^{2}$ It is likely that the patient described in the letter ${ }^{1}$ also developed her infection as a result of an indwelling intravenous cannula, although the letter does not state the method of intravenous access for the infusion of methylprednisolone, whether the same intravenous access was maintained for the five days of pulse therapy (three alternate day pulses), and whether the cannula and intravenous access site were subsequently cultured for bacterial organisms which might have caused the overwhelming infection.

Pulse therapy in the 480 patients with rheumatoid arthritis reported in published studies has a low incidence of major and minor side effects, ${ }^{3}$ and infections have rarely complicated the treatment in reported series.

As a result of our experience with one case of infection as a direct result of an intravenous cannula we no longer use indwelling cannulae to give pulse therapy. Both oral ${ }^{4}$ and intravenous $^{5}$ pulse therapy are given in our hospitals as outpatient procedures with no serious complications (particularly infective ones) being reported. It is difficult to see how giv̈ng pulse therapy to the patient at an outpatient clinic would have altered the outcome in the case reported because she developed an overwhelming infection and died despite being in hospital.

Therefore, despite the unfortunate demise of the patient reported I maintain that pulse therapy can be safely given as an outpatient procedure as long as sensible precautions for intravenous cannulation are used or pulse therapy is given orally. Continuing studies suggest that the efficacy and toxicity of intramuscular gold therapy in patients with rheumatoid arthritis is favourably influenced by the addition of pulse methylprednisolone therapy in the first three months of disease modifying antirheumatic drug treatment. ${ }^{5}$

$$
\begin{array}{r}
\text { MALCOLM D SMITH } \\
\text { Department of Rheumatology } \\
\text { Flinders Medical Centre } \\
\text { South Road } \\
\text { Bedford Park } \\
\text { South Australia S042 }
\end{array}
$$

1 Walsh D A, Durance R A. Fatal acute pyelonephritis following pulsed methylprednisolone nephritis following pulsed methylprednisolone
for rheumatoid arthritis. Ann Rheum Dis 1990; 40: rheuma $955-6$.

2 Smith M D, Bertouch J V, Smith A M, et al. The mith M D, Bertouch J V, Smith A M, et al. The
clinical and immunological effects of pulse methylprednisolone therapy in rheumatoid arthritis. I. Clinical effects. $\mathcal{F}$ Rheumatol 1988, 15: 229-32.

3 Smith M D, Ahern M J, Roberts-Thomson P J. Pulsed methylprednisolone therapy in rheumatoid arthritis: Unproved therapy, unjustified therapy, or effective adjunctive treatment? $A n n$ Rheum Dis 1990; 49: 265-7.

4 Smith M D, Ahern M J, Roberts-Thomson P J Pulse steroid therapy in rheumatoid arthritis Can equivalent doses of oral prednisolone give similar clinical results to intravenous methylprednisolone? Ann Rheum Dis 1988; 47: 28-33.
5 Wong C S, Champion G, Smith M D, et al. Does steroid pulsing influence the efficacy and toxicity of chrysotherapy? A double blind, placebo controlled study. Ann Rheum Dis 1990; 49: $370-2$.

\section{Effects of eel calcitonin on rheumatoid} arthritis

Sir: We have obtained exciting results in the treatment of rheumatoid arthritis (RA) in our clinic by administration of elcatonin, an eel calcitonin derivative, which is a polypeptide consisting of 32 amino acids and an endocrine substance secreted from the thyroid. ${ }^{12}$ At present various treatments for RA are used but few have been found valuable. This study was undertaken to obtain information about treatment of RA with calcitonin.

Two hundred and fifty nine patients with $\mathrm{RA}$, according to the revised criteria of the American Rheumatism Association, ${ }^{3}$ were studied. Their stage and class were determined according to the criteria of Steinbrocker et al. ${ }^{4}$ Ten MRC units of calcitonin were given intramuscularly twice a week for six months to 172 patients with RA (age 54 (SEM 1) years, stage 2.8 (SEM 0.06)), who had not been treated with immunomodulators or immunosuppressants (calcitonin only group). Calcitonin and a corticosteroid were given in combination to 63 patients with RA (age 54 $(1 \cdot 4)$ years, stage $3 \cdot 1(0 \cdot 10)$ ) (combination group), who had been receiving various oral doses of corticosteroids and had also received calcitonin at the same dose and by the same route as the calcitonin only group. Twenty four patients with RA who had received neither calcitonin nor corticosteroids served as the control group (age $58(2 \cdot 5)$ years, stage $3 \cdot 0$ $(0 \cdot 18))$; some of this group had been receiving a non-steroidal anti-inflammatory drug.

In the calcitonin only group remarkable improvements in clinical symptoms and laboratory findings were noted after six months of calcitonin treatment. Class, pain, and morning stiffness were significantly $(p<0.01)$ improved in $148(86 \%)$ of the calcitonin only group. Additionally, grip strength of both hands, rheumatoid factor, C reactive protein, erythrocyte sedimentation rate, serum iron, haemoglobin, IgG, IgA, IgM, and albumin/globulin ratio were all significantly improved after six months of calcitonin treatment (table); all changes were significantly $(p<0.05)$ different compared with the control group.

In the combination group no significant improvements were seen in grip strength (left), C reactive protein, erythrocyte sedi-

Improvements in symptoms and laboratory findings in patients with rheumatoid arthritis after calcitonin treatment. Values are given as means (SEM)

\begin{tabular}{lcc}
\hline & Before & After \\
\hline Grip strength (mmHg) & & \\
Left & $66(4 \cdot 3)$ & $89(5 \cdot 1)^{* *}$ \\
Right & $75(4 \cdot 8)$ & $99(5 \cdot 3)^{* *}$ \\
Classt & $2 \cdot 5(0 \cdot 06)$ & $1 \cdot 5(0 \cdot 06)^{* *}$ \\
Rheumatoid factort & $2 \cdot 4(0 \cdot 06)$ & $2 \cdot 1(0 \cdot 06)^{* *}$ \\
C reactive protein (mg/l) & $23(0 \cdot 8)$ & $14(1 \cdot 6)^{* *}$ \\
Erythrocyte sedimentation rate $(\mathrm{mm} / \mathrm{h})$ & $51(2 \cdot 8)$ & $39(2 \cdot 7)^{* *}$ \\
Serum iron ( $\mu$ mol/) & $11 \cdot 6(0 \cdot 3)$ & $12 \cdot 7(0 \cdot 5)^{* *}$ \\
Haemoglobin $(\mathrm{g} / \mathrm{l})$ & $122(1 \cdot 5)$ & $129(1 \cdot 4)^{* *}$ \\
IgG (g/) & $20 \cdot 1(0 \cdot 4)$ & $19 \cdot 5(0 \cdot 4)^{*}$ \\
IgA (mg/l) & $4150(133)$ & $3830(114)^{* *}$ \\
IgM (mg/l) & $2750(81)$ & $2580(75)^{* *}$ \\
Albumin/globulin ratio & $1 \cdot 31(0 \cdot 26)$ & $1 \cdot 50(0 \cdot 05)^{* *}$
\end{tabular}

${ }^{*} p<0.05 ;{ }^{* *} p<0.01$ for comparison of values at the start of the study and after six months' treatment. Results analysed by Student's $t$ test or +Wilcoxon's signed rank test.

mentation rate, serum iron, and haemoglobin, IgG, IgA, and albumin/globulin ratio. Improvements were found in class $(p<0.01)$ grip strength (right) $(p<0.05)$, rheumatoid factor $(p<0.01)$, and IgM $(p<0.05)$, but the improvements in grip strength and rheumatoid factor were significantly $(p<0.01)$ less than those in the calcitonin only group. There were no significant improvements in clinica signs and symptoms or laboratory data in the control group.

Thus this study has shown that the clinical signs and symptoms of RA as well as laboratory data are dramatically improved in the group treated with calcitonin alone. It has been reported that calcitonin has an antiinflammatory effect in rats with adjuvant arthritis. $^{56}$ In the calcitonin only group decreases in $\mathrm{C}$ reactive protein and erythrocyte sedimentation rate were noted after calcitonin treatment, indicating that the inflammatory response was suppressed by calcitonin. In addition, however, reductions in IgG, IgA, and IgM also occurred after calcitonin treat ment, resulting in an increase in albumin/ globulin ratio and a decrease in rheumatoid factor. These results suggest that calcitonin has an effect on the immunological mechanism of RA. It is reasonable to suggest, therefore, that the suppression of inflammation was subsequently brought about by an immunomodulating effect of calcitonin as the reduction of immunoglobulins cannot be attributed to suppression of the inflammatory response. This interpretation seems to be supported by the findings that both serum iron and haemoglobin significantly increased, because anaemia associated with RA is thought to be induced by the deposition of iron in the synovial tissue after repeated small haemorrhages caused by the immunological reaction in the joints.

Thus it seems that calcitonin may be considered for use as a remission inducing drug in RA. Corticosteroid treatment, however, apparently interfered with the beneficial effects of calcitonin treatment.

SUMIHISA AIDA Pain Clinic bashi Hospital Niigata 950 Japan

1 Friedman J, Reisz G. Thyrocalcitonin: inhibitor of bone resorption in tissue culture. Science 1965; 150: 1465-7.

Aliapoulis $M$ A, Goldhaber P, Munson P L. Thyrocalcitonin inhibition of bone resorption induced by parathyroid hormone in tissue culture. Science 1966; 151: 330-1.

3 Arnett F C, Edworthy S M, Bloch D A, et al. The 
American Rheumatism Association 1987. Revised criteria for the classification of rheumatoid arthritis. Arthritis Rheum 1988; 31: 315-24.

4 Steinbrocker O, Traeger C H, Batterman R C. Therapeutic criteria in rheumatoid arthritis. Therapeutic criteria in rhe
$\mathcal{J} A M A$ 1949; 140: 659-62.
5 Bogalk G R, Aldred J P, Kleszynski R R, Stubbs $\mathbf{R} \mathbf{K}$, Zeedyk R A, Bastian J W. Effects of salmon calcitonin and combination drug therapy on rat adjuvant arthritis. Agents Actions 1974; 4: 364-9.

6 Abdullai S E, Martelli E A, Bramm E, Franco L, Velo G P. Effect of calcitonin on different inflammatory models. Agents Actions 1977; 7: 533-8.

7 Mowat A G, Hothersall T E. Nature of anaemia in rheumatoid arthritis. VIII. Iron content of synovial tissue in patients with rheumatoid arthritis and normal individuals. Ann Rherm Dis 1968; 27: 345-51.

\section{ACKNOWLEDGMENTS}

The Editor wishes to thank the following who have generously given their time to help with the assessment of manuscripts during 1990

\begin{tabular}{|c|c|c|c|}
\hline Ali S Y & Doyle D & Jenner J R & Reid D M \\
\hline Ansell B & Duance V C & Jessop J D & Revell P \\
\hline Archer J R & Duff G & Johnson G D & Ring $E$ F S \\
\hline Arnott W G & Eales L-J & Jose $P$ & Rowe I F \\
\hline Asherson $\mathbf{R}$ & Eastmond C J & Jubb R W & Saari $\mathbf{H}$ \\
\hline Ayad S & Ebringer A & Keat A C S & Scott D G I \\
\hline Bamji A N & Edwards J C W & Kingsley G & Scott D L \\
\hline Barnes C G & Elson C J & Kirwan J R & Scott J T \\
\hline Bayliss M & Everson G & Knight $\dot{S}$ & Seagal A W \\
\hline Belch J & Fauci A S & Konttinen $\mathrm{Y} T$ & Seifert $M \mathbf{H}$ \\
\hline Bernstein $\mathbf{R} \mathbf{M}$ & Flower R J & Kyle V & Shapiro L $M$ \\
\hline Beverley $\mathbf{P}$ & Freemont A J & Lanchbury J S & Shipley $M$ E \\
\hline Bhalla A & Grahame R & Lanham J G & Silman A \\
\hline Binder A & Grange W & Lehner T & Simmonds A \\
\hline Bird H A & Gray $\mathbf{R}$ & Lessof $\mathbf{M ~ H}$ & Smith M D \\
\hline Black C & Grennan D M & Levick J R & Snaith M L \\
\hline Blake D $\mathbf{R}$ & Griffiths I D & Lunec $\mathbf{J}$ & Spector T D \\
\hline Bresnihan B & Grodzinsky A J & Macfarlane D & Speight $\mathbf{P} \mathbf{M}$ \\
\hline Brown D L & Grootveld M & Maddison P J & Stanworth D R \\
\hline Butler P & Haeney $M R$ & Malcolm A J & Sturrock R D \\
\hline Calin A & Hall N D & Mason $\mathbf{R}$ & Swannell A J \\
\hline Cambridge $\mathbf{J}$ & Hamilton E B D & Melsom R D & Swash M \\
\hline Cantor D & Hardingham $T$ & Mercer C & Szypryt $\mathbf{P}$ \\
\hline Capell $\mathbf{H}$ & Hazleman B & Moll J M H & Taylor-Robinson D \\
\hline Cawley M I D & Henderson B & Morgan $\mathrm{K}$ & Tyler J A \\
\hline Chamberlain M A & Hickling $\mathbf{P}$ & Morris C J & Venables $\mathbf{P}$ \\
\hline Clague R B & Hollingworth R P & Myles A B & Vischer $\mathbf{T} \mathbf{L}$ \\
\hline Clarke A $\mathrm{K}$ & Holt L P J & Palmer R G & Walport $\mathbf{M ~ J}$ \\
\hline Collins A J & Hughes G R V & Panayi G S & Watt I \\
\hline Corbett $\mathbf{M}$ & Huskisson E C & Pattrick M G & Webster A B D \\
\hline Crawford D & Hutton C W & Pepys M B & Weiss J B \\
\hline Crossman D C & Isenberg $\mathbf{D} \mathbf{A}$ & Perrett D & Whaley $\mathbf{K}$ \\
\hline Dawkins $\mathbf{R} \mathbf{L}$ & Iveson $\mathbf{J} \mathbf{M}$ & Poulter L W & Williams B D \\
\hline Day S & Jacoby $\mathbf{R} \mathbf{K}$ & Pounder R & Woo P \\
\hline Denman A $M$ & Janossy G & Powell R J & Woolf A D \\
\hline Dieppe P A & Jayson M I V & Pullar T & Woolley D \\
\hline Doherty M & Jenkins G & Ralston S & Wright V \\
\hline
\end{tabular}

